\title{
Laboratorial diagnosis of animal leptospirosis* Diagnóstico laboratorial de leptospirose animal
}

\author{
Ana Paula Loureiro, ${ }^{* *}$ Gabriel Martins, ${ }^{* *}$ Sabrina Thomé, ${ }^{* *}$ Walter Lilenbaum**
}

\begin{abstract}
Leptospirosis is the most widespread zoonosis in the world, but it is more prevalent in tropical than in temperate regions. Its etiologic agent, pathogenic Leptospira sp., penetrates the animal skin through cuts or abrasions, external mucosa (such as the conjunctiva). Clinical signs are variable and unspecific, particularly in animals, mainly in chronic infections, which are often asymptomatic. For an effective control of an infectious disease it is essential a diagnostic test that have high sensitivity, specificity and practicality. In leptospirosis, misdiagnosis is frequent, what can lead to erroneous treatment in cases of acute disease and to the maintenance of the agent in herds, what could determine considering losses. Noteworthy that the natural course of the disease influences directly on which diagnostic test should be chosen, as well as the type of clinical sample that should be collected. The laboratory diagnosis of leptospirosis is challenging, where there is not a highly sensitive and specific test for a reliable diagnosis in animals. This review presents advantages and disadvantages of the current laboratory methods for animal leptospirosis diagnosis considering the differences between affected species and the disease pathogenicity.
\end{abstract}

Keywords: bacteriology, diagnosis, Leptospira, leptospirosis, PCR, serology.

\begin{abstract}
Resumo
A leptospirose é a zoonose mais amplamente disseminada pelo mundo, porém é mais comum em regiões tropicais do que em regiões temperadas. Seu agente etiológico, Leptospira sp., penetra ativamente no organismo do animal através de cortes ou abrasões na pele, mucosa externa (como por exemplo a conjuntiva) ou até mesmo na pele íntegra quando em contato por tempo prolongado em coleções de água contaminada. Seus sinais clínicos são variáveis e inespecíficos, particularmente em animais, nos quais muitos casos se apresentam assintomáticos. Para um controle efetivo de uma doença infecciosa, é essencial o desenvolvimento de um teste diagnóstico que apresente alta especificidade, sensibilidade e praticidade. No caso da leptospirose, o erro diagnóstico é frequente, o que pode induzir ao tratamento errôneo, nos casos de doença aguda, e também a manutenção do agente em um rebanho, o que gera muitas perdas. O curso natural da doença influencia diretamente no tipo de método diagnóstico que deve ser eleito, assim como no tipo de amostra que deve ser coletada. O diagnóstico laboratorial da leptospirose ainda é um desafio, onde não existe um método altamente sensível e específico que promova um diagnóstico confiável em animais. Esta revisão tem por objetivo apresentar as vantagens e desvantagens dos métodos diagnósticos disponíveis, considerando as diferenças entre as espécies afetadas e da patogenia da leptospirose.
\end{abstract}

Palavras-chave: bacteriologia, diagnóstico, Leptospira, leptospirose, PCR, sorologia.

\section{Introduction}

Leptospirosis is the most widespread zoonosis in the world, but the disease is it is more prevalent in tropical than in temperate regions (Desvars et al., 2011). Leptospires are bacteria belonging to the family Leptospiraceae, order Spirochaetales. There are currently two different taxonomic classifications: serological and genotypic. Serological classification divides leptospires into serovars defined by the cross-agglutinin absorption test (CAAT), which are then grouped into serogroups according to the antigenic similarity of their LPS and the possibility of crossreactions. This classification has identified approximately 300 serovars, being more than 200 considered pathogenic (Faine et al., 2000). Conversely, genotypic classification is based on identity between DNA samples. Based on this technique, 20 species of the genus Leptospira have been identified (Smythe et al., 2012). The adoption of the genotypic classification turns the identification of leptospires difficult. Additionally, there is no complete correlation between serologic and genotypic classification: the same serovars may be found in more than one species and some species contain both pathogenic and non-pathogenic serovars. Thus, in order to accurately track the epidemiology of leptospirosis, it is essential to identify not only serologically but also the genomospecies of the leptospiral isolates (Djelouadji et al., 2012).

The clinical presentation of leptospirosis is unspecific; due to this, misdiagnosis is frequent. The definitive diagnosis relies on laboratorial results, which is still a really challenging (Musso and La Scola, 2013). The Microagglutination test (MAT) is the official diagnostic method recommended by both the human and animal health organizations (World Health Organization -WHO, 2010; World organization of animal health - OIE, 2012). It is serogroup-specific and not adequate for determining infection in a serovar level. Likewise, the diagnosis based on the genomic detection in clinical samples does not allow an identification of

*Recebido em 27 de agosto de 2013 e aceito em 14 de outubro de 2013

**Laboratório de Bacteriologia Veterinária, Universidade Federal Fluminense, Niterói/RJ, Brasil. Corresponding author: mipwalt@vm.uff.br (W. Lilenbaum). 
the serovar, what is particularly important for epidemiological studies (Picardeau, 2013). This review presents the advantages and disadvantages of the current laboratory methods for the diagnosis of animal leptospirosis, considering the differences between affected species and the disease pathogenicity.

\section{Animal leptospirosis}

Leptospires penetrate actively in the animals through cuts or abrasions of the skin; mucosa, such as the conjunctiva and genito-urinary (Lilenbaum et al., 2008), or the intact skin when it is prolonged in collections of contaminated water (Adler and de la Peña Moctezuma, 2010). After penetration, leptospires multiply in organic humors (blood, lymph and cerebrospinal fluid), featuring leptospiremia phase, when leptospires are spread throughout the host organism (Monahan et al., 2009). That phase takes approximately ten days, until the concentrations of specific immunoglobulins rise in the blood. These immunoglobulins opsonize bacteria, with subsequent removal of the leptospires of circulation (Adler and de la Peña Moctezuma, 2010). When the host immune response is effective in removing the leptospires from blood circulation and able to overcoming the damage and consequent functional changes, starts the second phase, characterized mainly by leptospiruria. This is referred to as the immune phase with circulating antibodies, and the presence of leptospires in urine (Bharti et al., 2003).

Even after the onset of immune phase, leptospires may persist colonizing various organs. Probably, locals like the interstice of the kidney is relatively protected from immune attack, for having lower blood supply (Monahan et al., 2009). Bacteria reside and form colonies in the lumen of the renal tubules of the animal host that spread leptospires in the environment, which is the main factor in the dissemination of the agent (Bharti et al., 2003).

Depending on the host species and the infecting serovar, that chronic phase may take several years, and spreading of leptospires in urine is referred to be intermittent. In this case, the shedder animal is known as reservoir, or simply, carrier or host (Faine et al., 2000). The occurrence and severity of the clinical symptoms depends on the interaction between the host and the infecting serovar. Some serovars tend to cause chronic and often subclinical disease in a determined host species, called host-adapted, while non-adapted serovars usually determine acute and severe disease. Among the serovars described as host-adapted, there are Canicola in dogs, Bratislava in horses, Pomona in pigs, Hardjo in ruminants and Icterohaemorrhagiae in rats. (Suepaul et al., 2011; Sykes et al., 2011), as shown on Table 1.

Table 1: Comparison between host adapted and incidental infections in animal leptospirosis

\begin{tabular}{cc}
\hline \hline Adapted serovars & Incidental serovars \\
\hline Affected species is the reservoir & Dependent of other species \\
Frequent occurrence & Infrequent occurrence \\
Endemic & Epidemic (outbreaks) \\
Less influenced by environmental factors & Dependent of environmental factors \\
Chronic or sub-clinical & Acute \\
Silent & Rich in symptoms \\
Low immune response & Intense immune response \\
IgG predominant & IgM predominant \\
\hline \hline
\end{tabular}

The incidental disease also varies according to the affected species. In dogs from tropics, it is most frequently determined by serovars Icterohaemorrhagiae and Copenhageni (both from serogroup Icterohaemorrhagiae). It classically presents as an acute and severe form, which resembles the typical Weil's disease of human beings. Typically, the incidental acute leptospirosis in dogs present with fever, jaundice, vomiting, diarrhea, intravascular disseminated coagulation, uremia caused by renal failure, hemorrhages and may frequently lead to death (Goldstein, 2010).The reservoirs of those serovars are rodents, mainly the Norway rat (Rattus norvegicus), while the role of wild rodents and marsupials in Brazil, as the brow rat, capybaras or opossums remains to be elucidated. Conversely, the chronic disease determined by the adapted serovar (Canicola) leads to chronic renal insufficiency, which is generally mild and are frequently misdiagnosed (Andre-Fontaine et al., 2006).

In livestock, signs of leptospirosis are mainly characterized by reproductive failure, abortion, stillbirths, fetal mummification and weak piglets or calves. When determined by host-adapted serovares, the disease is endemic with a few cases that happens permanently and all over the year. When associated to incidental infection, it usually presents as an outbreak, with a large number of cases in a short period of time, and severe symptoms (Grooms and Bolin, 2005; Ramos et al., 2006; Martins et al., 2012). Nevertheless, in young animals, the disease may develop a more severe presentation as an acute infection, in which signs such as fever, jaundice, and hematuria are present, with high mortality (Grooms and Bolin, 2005).

In horses, the most described clinical sign associated to leptospirosis is the recurrent uveitis, also known as moon blindness, in which the leptospiral epitopes cross-react with ocular proteins that are then recognized by the horse's immune system as non-self (Gilger et al., 2008). Additionally, leptospirosis is also a reproductive disease since it leads to abortion, stillbirth, prematurely born foals and early embryo death, which are strongly associated to Bratislava infection - formerly the host adapted serovar for horses (Pinna et al., 2013). Nevertheless, subclinical forms are very common, particularly in endemic regions (Jung et al., 2010; Houwers et al., 2011).

\section{Laboratorial diagnosis}

For an effective control of an infectious disease it is essential a viable diagnostic test that have high sensitivity, specificity and practicality (Palaniappan et al., 2007). The lack of an ideal laboratory test for detection of animal leptospirosis, however, remains a major barrier to diagnosis and surveillance (Hartskeerl et al., 2011).

Noteworthy that the natural course of the disease influences directly on which diagnostic test should be chosen and the type of clinical sample that should be collected (Picardeau, 2013).

During leptospiremia (acute and initial phase), the agent can be easily detected in whole blood samples, cerebrospinal fluid and other humors of the animal. But at this stage the humoral immune response is not yet established and the animals usually do not show detectable serological titres in conventional serological tests. Meanwhile, when there is leptospiruria, leptospires are intermittently released in the urine and hardly detected in the 
blood. At this time, the animals develop an immune response with detectable serologic titres (OIE, 2012).

When the animal comes to death, liver, lung, brain and kidneys samples can be collected for analysis (OIE, 2012). In abortions, besides the above mentioned, leptospires could be detected in blood, cerebrospinal fluid and gastric juice (OIE, 2012; Hamond et al., 2012a).

The goal of the diagnosis is another important point that should be highlighted when choosing a method. During the acute disease, the elected diagnostic method must have the ability to obtain a definitive diagnosis prior to the detection of antibodies, while treatment may be more effective (Musso and La Scola., 2013). In this case a method directed towards the demonstration of the agent, such as PCR, is often more appropriate than serological methods. Meanwhile, leptospirosis in livestock is a collective disease and has to be evaluated in a herd level. In this instance, serological tests were shown as acceptable tools to screen for leptospirosis in order to detect infected herds (Otaka et al., 2012; Hamond et al., 2012b).

\section{Traditional direct methods of diagnosis}

\section{Microscopy}

Leptospires are very thin organisms $(10-20 \mu \mathrm{m})$ and are hardly seen by traditional staining methods, as Gram or Giemsa. Dark field microscopy (DFM) principle is based on the reflections from the surface of the microorganism magnified by the microscope. In this case, when the lens is focused on leptospires, this bacterium is viewed as an object with bright contrasting dark background (Faine et al., 2000). Approximately $10^{4}$ leptospires/ $\mathrm{mL}$ are necessary for one cell per field to be visible by DFM. The drawback of DFM on clinical specimens as a diagnostic tool has been that both false-positive and false-negative diagnosis can be easily made, even in experienced hands (Ahmad et al., 2005). Approximately $10^{4}$ leptospires $/ \mathrm{mL}$ are necessary to observe one cell per field. The result is also affected by the timing of sample collection and the skill of the laboratory personnel. Leptospires in blood can be detected only during the first few days after onset. Direct examination of blood or urine by darkfield microscopy can lead to misclassification of threads of fibrin, other proteins, or even hair that might be accidentally in the sample as leptospires. Thus, this should not be used as a definitive laboratory test, but as an adjunct to other diagnostic methods (Toyokawa et al., 2011).

Staining methods have been applied in order to increase the sensitivity of direct microscopic examination on blood, urine and others tissues form suspect animals. These include Warthin-Starry silver stain (WS), a non-specific impregnation method, and the specific direct immunofluorescence (IF) or Immunohistochemistry (IHC) (Ahmad et al., 2005). WS and IF techniques allow the direct visualization of the whole bacteria in the clinical samples, what represents the main advantage of those methods. The IF is particularly useful for detection of outer membrane antigens (Fornazzari et al., 2012). Limitations of IF are the lack of information about tissue morphology, the difficulty of preserving the results and the need for special fluorescence microscopy equipment. In contrast, IHQ does not require a special microscope and provides an opportunity to examine the distribution and localization of antigen in tissue sections. Moreover, this method enables retrospective studies using formalin-fixed and paraffin-embedded tissue samples (Szeredi and Hake, 2006).

\section{Bacteriological Culturing}

Leptospira isolation is considered as the gold standard diagnosis, however it is hampered by the slow growth rate of the bacterium (Adler and de la Peña Moctezuma, 2010). Another limitation of this method is that the samples have to be inoculated in specific culture media immediately after collection (Faine et al., 2000; Levett, 2001).

Leptospires can be isolated from clinical materials such as blood, cerebrospinal fluid, urine and post-mortem tissues samples. Tissue samples should be macerated before the inoculation in liquid medium. For fluid samples, a few drops of blood are inoculated into $5-10 \mathrm{ml}$ of a suitable culture medium such as Ellingausen-McCullough- Johnson-Harris (EMJH) medium, modified Korthof medium or semi-solid Fletcher medium (Faine et al., 2000).

Contamination of the cultures by other microorganisms occurs frequently; particularly in cases of clinical specimens such as urine were obtained by spontaneous voiding. Filtration through $0.22 \mu \mathrm{m}$ micropores membranes or adding selective antimicrobial agents or chemotherapeutic on traditional media culture are procedures that are frequently adopted in order to prevent or eliminate the contamination, but that makes the method costly and laborious, and is very often ineffective (Rahelinirina et al., 2010; Chakraborty et al., 2011).

Inoculated media must be maintained incubated at $28-30{ }^{\circ} \mathrm{C}$ and examined weekly by DFM to 20 weeks before being discarded with negative result. Therefore, culture is not considered effective as a routine diagnostic test, being more performed for research studies. Despite the high specificity, it has low sensitivity and can take up to three months for the release of a negative result (Faine et al., 2000; Ahmad et al., 2005; Toyokawa et al., 2011).

However, the isolation of bacteria plays an important role in epidemiological investigations, being precondition for the identification of strains involved in infections in a certain geographic area (Chakraborty et al., 2011; Desvars et al., 2012).

\section{Indirect diagnostic methods}

\section{Antibody detection - serology}

Serological methods have been used over the years as evidence of the host response to a leptospiral exposure. Depending on the applied method, binding antibodies are detected in blood approximately ten days after infection (Faine et al., 2000; Levett, 2001). In that moment, due to the lower probability of leptospires detection in blood, serologic methods become required. In fact, even during the leptospiruria phase, direct methods may be uncertain, since elimination of microorganisms in urine is referred to be intermittent (Adler and de la Peña Moctezuma, 2010).

\section{Microscopic agglutination test (MAT)}

The microscopic agglutination test (MAT) is the serological test recommended for the diagnosis of leptospirosis for both human beings (WHO, 2010) and animals (OIE, 2012). The basis of the test is the detection of agglutination reactions between serum antibodies and outer membrane antigens of live leptospires. After incubation, the serum-antigen mixture is examined by DFM in 
order to evaluate the agglutination percentage and determine the serological titre (Chappel et al., 2004).

Although widely utilized and recommended, MAT has important and well-known limitations. A panel of Leptospira serovars should be kept alive in liquid media $(E M J H)$, what requires repeated weekly reviews and subculture of a large number of strains, presenting hazards for laboratory workers (Ahmad et al., 2005; Toyokawa et al., 2011). As a minimum, the panel should include all locally circulating serovars and an incomplete panel may be responsible for false negative results (Musso and La Scola, 2013).

The method is laborious and requires well-trained and experienced observers to minimize the probability of error, as the reading of agglutination is subjective and interlaboratory variation in results is high (Levett, 2001; Bharti et al., 2003). Furthermore, the test is complex to control and perform; it cannot be standardized since live leptospires are used as antigens (Musso and La Scola, 2013).

With respect to the ability to identify the infectious serovar, it is a consensus that MAT can identify the presumptive serogroup in a reliable basis, but, due to the high degree of cross-reaction among different serovars in each serogroup, it cannot be considered as serovar-specific (Ahmad et al., 2005).

MAT detects antibodies from both $M$ and $G$ classes, and cannot differentiate between current, recent, or past infections, or even differentiate those decurrently from the natural infection from the vaccinal antibodies (Limmathurotsakul et al., 2012). The current interpretive criteria indicative of active infection for MAT requires a fourfold rise in titer between the acute and convalescent sera. Although it is well recognized that seroconversion or increasing antibody titres in paired serum specimens provides strong evidence for true infection, paired serology is not practical in the clinical setting, particularly for livestock (Yan et al., 2013).

\section{Enzyme-Linked Immunosorbent Assay (ELISA)}

Due to the several limitations of MAT, and complexity of its interpretation, several tests to detect anti-Leptospira immunoglobulins have been developed with the purpose of replace or complement it, as rapid tests and ELISAs (Hamond et al., 2012c). Different ELISAs have been developed for human and others animals. Advantages of those assays are the ability to distinguish between acute and chronic infection by detection of specific immunoglobulins $\lg \mathrm{M}$ or $\lg \mathrm{G}$ (and, eventually, $\lg \mathrm{A}$ ); high sensitivity and specificity, and high repeatability when compared with MAT (Flannery et al., 2001). Conversely, depending on the employed antigen, a positive result on ELISA gives no indication on the infecting serovar/serogroup and is not sufficient to diagnose a case of leptospirosis, what must be confirmed by PCR, or culture (Picardeau, 2013).

Development of a single specific antigenic reagent suitable for serological detection of infections with all serovars remains a great challenge. ELISA kits based on the detection of antibodies against a total extract of leptospires, usually the saprophytic strain $L$. biflexa or the intermediate species $L$. fainei, which shares several surface antigens with pathogenic strains, are available (Picardeau, 2013). The immunodominant antigen share in wholecell preparations appears to be a broadly reactive disaccharide epitope present in nonpathogenic leptospires, as well as a diverse group of nonleptospiral species (Flannery et al., 2001).

In the last years, several Leptospira surface proteins have been identified and characterized, including the outer membrane proteins (OMP) LipL36, LipL41, LipL32, Loa22, Len family, and the Lig proteins, all of which have been used in leptospirosis diagnosis studies (Hartleben et al., 2013). With that, several ELISA protocols were developed with different recombinant antigens in animals (Dey et al., 2004; Bomfim et al., 2005; Sankar et al., 2010; Subathra et al., 2013; Hartleben et al., 2013). Recombinant protein-based serologic tests may achieve high sensitivity and specificity because of the high concentration of immunoreactive antigens which can be used in assays, and the lack of nonspecific moieties present in whole-cell preparations. An ideal antigen would be a principal target of the host immune response, expressed only in pathogenic leptospires and conserved among the more than 200 serovars associated with human disease in different geographic regions and epidemiological situations (Flannery et al., 2001).

LipL32 is the major Leptospira protein studied as antigen for ELISA protocols for use in different animals (Dey et al., 2004; Bomfim et al., 2005; Hartleben et al., 2013). This is the most abundant antigen found in the leptospiral total protein profile, highly conserved among pathogenic species but absent in saprophyte species; the surface lipoprotein LipL32 was also identified as an immune target during natural infection by leptospires (Hartleben et al., 2013). Sensitivity (SE) and specificity (SP) results of ELISA protocols using recombinant LipL32 antigens (rLipL32 ELISA) are encouraging. Studies present $97 \%$ of SE and SP in dogs (Dey et al., 2004); $100 \%$ of SE and SP in cattle (Bomfim et al., 2005) and $100 \%$ SE, $85.1 \%$ SP in swine (Hartleben et al., 2013) when rLipL32-ELISA was compared with MAT.

Others recent studies using recombinant proteins such as OMPL 1 in dog's serum with $100 \%$ SE and $94.3 \%$ SP (Subathra, et al., 2013); Lig B (Sankar et al., 2010) and LipL21(Joseph et al., 2012) in cattle both presented $100 \%$ SE and $97.1 \%$ SP showed that all the studied protocols have similar results when compared with MAT.

\section{Other serological tests}

Several rapid serological tests were described for the diagnosis of the acute infection on humans, but all of them have limited sensitivity, low specificity and are only used as screening methods. They are based on four immunological principles: i) particle agglutination; ii) immunodot or dipstick/comb; iii) immunofiltration or flow-through device; iv)immunochromatography or lateral flow (Musso and La Scola, 2013).

For veterinary diagnosis, a rapid slide test (RSAT) was developed as a screening technique for early detection of anti- Leptospira antibodies in the acute disease of dogs (Lilenbaum et al., 2002) and horses (Hamond et al., 2012c). This test is based on the antibody agglutination with a whole bacteria antigen preserved in formaldehyde. The suspension of antigens must contain the most frequent serovars in the considered region. The RSAT is not able to identify the infecting serovar and, as described above for ELISA, results cannot be applied on epidemiological concerns. Results interpretation must be associated with clinical symptoms, since the result may be doubtful due to the possibility of cross reactions. 


\section{Advanced direct methods}

\section{Molecular diagnosis}

Polymerase Chain Reaction (PCR) as a diagnostic tool for leptospirosis in animals has been increasingly used in the last years (Pinna et al., 2011). The value of this technique is mainly observed for the carrier detection within a herd or even on early diagnosis of an animal stricken with the most severe form of leptospirosis (Hamond et al., 2012b; Otaka et al., 2012). This technique presents high sensitivity and specificity, allowing the amplification of minimum quantities of the microorganism DNA in various types of biological samples in a rapid procedure (Hernández-Rodríguez et al., 2011). Some molecular systems are sensitive enough to detect 10 to 100 copies of leptospiral genome per milliliter of sample (Bourhy et al., 2011). However, it has limitations such as the inability to identify the infecting serovar, thus not contributing to the advancement in epidemiological studies (Ahmad et al., 2005).

PCRs fall into two categories based on the detection of genes that are universally present in bacteria, as gyrB (Slack et al., 2006), 16S rRNA gene, or rrs (Merrien et al., 1992) and secY (Ahmed et al., 2009); or detection of genes that are restricted to pathogenic Leptospira spp. such as lipL32 (Stoddard et al., 2009; Hamond et al., 2012b), ligA and ligB (Palaniappan et al., 2005) which the later ones are more effective for early diagnosis in clinical specimens.

Recently, a number of real-time/quantitative PCRs (qPCR; SYBR Green or Taqman technology) were reported for substitute the traditional PCR, since they are faster than regular PCR and less sensitive to contaminations (Ahmed et al., 2009). Another characteristic of the qPCR is the DNA quantification on the sample. Nevertheless, in human analyses, no correlation has currently been found between the bacterial load detected in clinical sample and the patient's prognosis (Picardeau, 2013). Despite its advantages front of traditional PCR, the use of qPCR is still very expensive for commercial veterinary use.

\section{Typing methods}

Typify a recently isolated Leptospira strain is still a challenge because of the taxonomic conflicts. Although the serological classification has no taxonomic value, establishing the infecting serogroup or serovar is useful for identifying reservoirs and for developing preventive strategies (Salaün et al., 2006). Serological classification at serogroup and serovar levels is based on cross-agglutination tests and agglutinins absorption with hyperimmune sera (Paiva-Cardoso et al., 2013). These methods are restricted to a few references laboratories and require a pure and well grown culture to perform these tests. Moreover, the interpretation of the results is complicated due to the frequent cross-reactions that occur among serogroups. The methods are also difficult to standardize because they depend on the biologist operating the microscope (Salaün et al., 2006).

Current typing of Leptospira strains requires a combination of both serological and molecular methods in order to allow the precise identification of field isolates (Paiva-Cardoso et al., 2013). Species determination could be performed by conserved genus sequencing. The usual target for sequence-based identification of Leptospira species is the 16SrRNA, or rrs gene. Other genes such as gyrB (Slack et al., 2006), rpoB (La Scola et al., 2006) or secY (Ahmed et al., 2006) has also been successfully used to differentiate leptospiral species.

Matrix-assisted laser desorption ionisation-time-of-flight mass spectrometry (MALDI-TOF-MS) emerged over the last years as a first-line technique for the rapid identification of several bacteria (Sauer and Kliem, 2010). That is a fast and easily applied method for bacteria classification at the species level. Mass spectrometry detects and compares individual protein mass peaks of bacterial cells. Samples can either be spotted as native bacteria cells (direct smear), or an additional extraction step can be performed to purify the proteins of the bacteria (Rettinger et al., 2012). The usefulness of MALDI-TOF-MS as a rapid, cheap and reliable identification of Leptospira isolates at the species level was proven, and a reference Leptospira database was created and is available online to allow easy comparison of results in other laboratories (Djelbuadji et al., 2012). This method can be used as a comparable tool to the well-established molecular genetic typing methods like MLST. Species confirmation by MALDI-TOF MS is faster and more easily applied as compared with the other and more elaborate molecular typing methods (Rettinger et al., 2012).

Although serogroup classification is not well related to molecular classification, serovars can be characterized by different molecular typing methods, such as restriction fragment length polymorphism RFLP (Djadid et al., 2009), randomly amplified polymorphic DNA, and pulsed-field gel electrophoresis - PFGE (Romero et al., 2009) However, these molecular methods have certain drawbacks: they require large amounts of DNA, are laborious and may not always be sufficiently discriminating or reproducible (Salaün et al, 2006).

Variable-NumberTandem-Repeat Loci was identified in some species of Leptospira gender and, by the Multi Locus VNTR Analysis (MLVA), could be possible the differentiation of most serovars of $L$. interrogans and L. kirschineri (Majed et al., 2005; Salaün et al., 2006, Bourhy et al., 2013). Strains from species L. borgpetersenii, L. noguchi, L. santarosai, and L. kmetyi could not be typed by this method because of the absence of one or more of the VNTR loci (Bourhy et al., 2013).

Whereas VNTR is the current method accepted worldwide, Mult locus sequence typing (MLST) promises a more straightforward characterization of $L$. interrogans isolates because it is amenable to standardization through available online databases, (such as leptospira.mlst.net), and allows access to current molecular epidemiology data from many laboratories (Caimi et al., 2012). Leptospira scheme supported by a public MLST database was currently only applicable to $L$. interrogans and $L$. kirschneri, but a recently study proposed a new MLST scheme that includes the seven most important species of pathogenic Leptospira (Booslip et al., 2013). MLST have been developed to differentiate the species and examines the intra- and interspecies relationships of Leptospira (Ahmed et al., 2006); that is a simple PCR-based technique that makes use of automated DNA sequencers to assign and characterize the alleles present in different target genes (Romero et al., 2009). The main advantages of MLST over other typing methods for leptospires include reproducibility, robustness, consistency and portability (Ahmed et al., 2006).

Nonetheless, because of difficulties in obtaining isolates of Leptospira from clinical samples (expense, expertise, problems with contamination, and intrinsically poor isolation rates), some 
typing methods directly from clinical samples have been studied recently (Agampodi et al., 2013). Bourhy et al. (2013) describe a PCR-based typing method for amplification of $r$ s, secY, and VNTR loci used directly on biological samples from humans with acute disease. In this disease phase, the bacterial load in blood during the acute phase ranges from $10^{2}$ to $10^{6}$ leptospires $/ \mathrm{mL}$, thus avoiding culturing of the pathogen. Thus, if the bacterial load is low, it may be necessary to use nested-PCR for amplification of the target sequences. Another full MLST typing scheme to directly identify infecting Leptospira in human clinical specimens was reported, but this present a relatively insensitive and poor amplification results (Agampodi et al., 2013).

\section{Concluding remarks}

The microagglutination test is widely used for the current diagnosis of leptospirosis as official recommendation. Despite its efficiency in the diagnosis of the acute clinical disease and for collective diagnosis (detection of infected herds) and determine

\section{References}

ADLER, B. ; DE LA PENA MOCTEZUMA, A. Leptospira and leptospirosis. Veterinary Microbiology, v. 27, n. 3-4, p. 287-296, 2010.

AGAMPODI, S.B.; MORENO, A.C.; VINETZ, J.M.; MATTHIAS, M.A. Utility and limitations of direct multi-locus sequence typing on qPCR-positive blood to determine infecting Leptospira strain. The American Journal of Tropical Medicine and Hygiene. v.88, n.1, p.184-185, 2013.

AHMAD, S.N,; SHAH, S.; AHMAD, F.M. Laboratory diagnosis of leptospirosis. Journal of Postgraduate Medicine, v. 51, n. 3, p.195200, 2005.

AHMED, N.; DEVI, S.M.; VALVERDE, Mde. L.; VIJAYACHARI, P.; MACHANG'U, R.S. ; ELLIS, W.A.; HARTSKEERL, R.A. Multilocus sequence typing method for identification and genotypic classification of pathogenic Leptospira species. Annals of Clinical Microbiology and Antimicrobials, v.5, n. 28, p. 1-10, 2006.

AHMED, A.; ENGELBERTS, M.F.; BOER, K.R.; AHMED, N.; HARTSKEERL, R.A. Development and validation of a real-time PCR for detection of pathogenic leptospira species in clinical materials. PLoS One, v.18, n. 9, p. e7093, 2009.

ANDRÉ-FONTAINE, G. Canine leptospirosis-do we have a problem? Veterinary Microbiology, v. 117, n. 1, p. 19-24, 2006.

BHARTI, A.R.; NALLY, J.E.; RICALDI, J.N.; MATTHIAS, M.A.; DIAZ, M.M.; LOVETT, M.A.; LEVETT, P.N.; GILMAN, R.H.; WILLIG, M.R.; GOTUZZO, E.; VINETZ, J.M. Leptospirosis: a zoonotic disease of global importance. The Lancet Infectious Diseases, v. 3, n. 12, p. 757-771, 2003.

BOMFIM, M.R.; KO, A.; KOURY, M.C. Evaluation of the recombinant LipL32 in enzyme-linked immunosorbent assay for the serodiagnosis of bovine leptospirosis. Veterinary Microbiology. v. 109, n. 1-2, p. 89-94, 2005.

BOONSILP, S.; THAIPADUNGPANIT, J.; AMORNCHAI, P.; WUTHIEKANUN, V.; BAILEY, M.S.; HOLDEN, M.T.; ZHANG, C.; JIANG, X.; KOIZUMI, N.; TAYLOR, K.; GALLOWAY, R.; HOFFMASTER, A.R.; CRAIG, S.; SMYTHE, L.D.; HARTSKEERL, R.A.; DAY, N.P.; CHANTRATITA, N.; FEIL, E.J.; AANENSEN, D.M.; SPRATT, B.G.; PEACOCK, S.J. A single multilocus sequence typing (MLST) scheme for seven pathogenic Leptospira species. PLOS Neglected Tropical Diseases. v. 7, n. 1, p. e1954, 2013. the infecting serogroup, the method has some critical limitations which must be taken into account. Among its limitations, the main one is the inability of the method to determine an individual definitive diagnosis, particularly in chronically and sub-clinically infected animals, and the impossibility of differentiation between vaccinated from infected animals. In contrast, $P C R$ is an efficient tool for the detection of carriers and also should be used as early diagnostic method on leptospiremia phase. The gold standard for diagnosis of leptospirosis is the bacteriological culture and consequent phenotypic characterization of the isolate, what has a huge epidemiological importance but is a laborious and slow technique. Therefore, molecular typing methods have been improved the Leptospira classification near to serovar level, and some techniques using PCR products from clinical specimens, without the necessity of culture have been developed successfully. The use of advanced diagnostic tools in veterinary medicine is still limited due to their high costs, but will probably be used as routine techniques in diagnostic laboratories in the near future.

BOURHY, P.; BREMONT, S.; ZININI, F.; GIRY, C.; PICARDEAU, $M$. Comparison of realtime $P C R$ assays for detection of pathogenic Leptospira spp. in blood and identification of variations in target sequences. Journal of Clinical Microbiology. v. 49, p. 2154-2160, 2011.

BOURHY, P.; HERRMANN STORCK, C.; THEODOSE, R.; OLIVE, C.; NICOLAS, M.; HOCHEDEZ, P.; LAMAURY, I.; ZININI, F.; BRÉMONT, S.; LANDIER, A.; CASSADOU, S.; ROSINE, J.; PICARDEAU, M. Serovar diversity of pathogenic Leptospira circulating in the French West Indies. PLOS Neglected Tropical Diseases. v.7, n. 3, p. e2114, 2013.

CAIMI, K.; VARNI, V.; MELENDEZ, Y.; KOVAL, A.; BRIHUEGA, B.; RUYBAL, P. A combined approach of VNTR and MLST analysis: improving molecular typing of Argentinean isolates of Leptospira interrogans. Memórias do Instituto Oswaldo Cruz. v.107, n. 5, p. 644-651, 2012.

CHAKRABORTY, A,; MIYAHARA, S.; VILLANUEVA, S.Y.; SAITO, M.; GLORIANI, N.G.; YOSHIDA, S. A novel combination of selective agents for isolation of Leptospira species. Microbiology and Immunology. v. 55, n. 7, p. 497-501, 2011.

CHAPPEL, R.J.; GORIS, M.; PALMER, M.F.; HARTSKEERL, R.A. Impact of proficiency testing on results of the microscopic agglutination test for diagnosis of leptospirosis. Journal of Clinical Microbiology. v. 42, n. 12, p. 5484-5488, 2004.

DESVARS, A.; CARDINALE, E.; MICHAULT, A. Animal leptospirosis in small tropical areas. Epidemiology and Infection, v. 139, n. 2, p. 167-188, 2011.

DESVARS, A.; NAZE, F.; VOURC'H, G.; CARDINALE, E.; PICARDEAU, M.; MICHAULT, A.; BOURHY, P. Similarities in Leptospira serogroup and species distribution in animals and humans in the Indian ocean island of Mayotte. The American Journal of Tropical Medicine and Hygiene, v.87, n. 1, p. 134-140, 2012.

DEY, S.; MOHAN, C.M.; KUMAR, T.M.; RAMADASS, P.; NAINAR, A.M.; NACHIMUTHU, K. Recombinant LipL32 antigen-based single serum dilution ELISA for detection of canine leptospirosis. Veterinary Microbiology. v.103, n.1-2, p. 99-106, 2004.

DJADID, N.D.; GANJI, Z.F.; GOUYA, M.M.; REZVANI, M.; ZAKERI, $S$. A simple and rapid nested polymerase chain reaction-restriction fragment length polymorphism technique for differentiation of pathogenic and nonpathogenic Leptospira spp. Diagnostic Microbiology and Infectious Disease. v. 63, n. 3, p. 251-256. 2009. 
DJELOUADJI, Z.; ROUX, V.; RAOULT, D.; KODJO, A.; DRANCOURT, M. Rapid MALDI-TOF mass spectrometry identification of Leptospira organisms. Veterinary Microbiology. v.158, n.1-2, p.142-146, 2012.

FAINE, S.; ADLER, B.; BOLIN, C.; PEROLAT, P. Leptospira and Leptospirosis. 2. ed. Austrália: MedSci, 2000, 271 p.

FLANNERY, B.; COSTA, D.; CARVALHO, F.P.; GUERREIRO, H.; MATSUNAGA, J.; DA SILVA, E.D.; FERREIRA, A.G.; RILEY, L.W.; REIS, M.G.; HAAKE, D.A.; KO, A.I. Evaluation of recombinant Leptospira antigen-based enzyme-linked immunosorbent assays for the serodiagnosis of leptospirosis. Journal of Clinical Microbiology. v. 39, n. 9, p. 3303-3310, 2001.

FORNAZARI, F.; DA SILVA, R.C.; RICHINI-PEREIRA, V.B.; BESERRA, H.E.; LUVIZOTTO, M.C.; LANGONI, H. Comparison of conventional PCR, quantitative PCR, bacteriological culture and the Warthin Starry technique to detect Leptospira spp. in kidney and liver samples from naturally infected sheep from Brazil. Journal of Microbiological Methods, v. 90, n. 3, p. 321-326, 2012.

GILGER,B.C.; SALMON, J.H.; YI, N.Y.; BARDEN,C.A.; CHANDLER, H.L.; WENDT,J.A.; COLITZ, C.M. Role of bacteria in the pathogenesis of recurrent uveitis in horses from the southeastern United States. American journal of veterinary research.v. 69, n.10, p.1329-1335, 2008.

GOLDSTEIN, R.E. Canine leptospirosis. Veterinary Clinics of North America: Small Animal Practice. v. 40, n.6, p.1091-1101, 2010.

GROOMS, D.L.; BOLIN, C.A. Diagnosis of fetal loss caused by bovine viral diarrhea virus and Leptospira spp. Veterinary Clinics of North America: Food Animal Practice. v. 21, n. 2, p. 463-472, 2005. HAMOND, C.; MARTINS, G.; LILENBAUM, W.; MEDEIROS, M.A. Rapid and efficient diagnosis of leptospirosis in an aborted foal by PCR of gastric juice. Veterinary Microbiology. v. 9, n.1-2, p. 274275, 2012a.

HAMOND, C.; MARTINS, G.; LILENBAUM, W.; MEDEIROS, M.A. PCR detection of leptospiral carriers among seronegative horses. Veterinary Record. v.171, n. 4, p.105-106, 2012b.

HAMOND, C. ; MARTINS, G. ; DINIZ, R. ; PENNA, B. ; LILENBAUM, W. Comparison of rapid-slide versus microscopic agglutination tests for equine leptospirosis. Online Journal of Veterinary Research. v. 16, p. 111-116, 2012c.

HARTLEBEN, C.P.; LEAL, F.M.; MONTE, L.G.; HARTWIG, D.D.; SEIXAS, F.K.; VASCONCELLOS, S.A.; BRIHUEGA, B.; DELLAGOSTIN, O.A. Serological analysis by enzyme-linked immunosorbent assay using recombinant antigen LipL32 for the diagnosis of swine leptospirosis. Current Microbiology. v. 66, n. 2, p. 106-109, 2013.

HARTSKEERL, R.A.; COLLARES-PEREIRA, M.; ELLIS, W.A. Emergence, control and re-emerging leptospirosis: dynamics of infection in the changing world. Clinical Microbiology and Infection. v.17, n. 4, p. 494-501, 2011.

HERNÁNDEZ-RODRÍGUEZ, P.; DÍAZ, C.A.; DALMAU, E.A.; QUINTERO, G.M. A comparison between polymerase chain reaction (PCR) and traditional techniques for the diagnosis of leptospirosis in bovines. Journal of Microbiological Methods. v. 84, n.1, p.1-7, 2011.

HOUWERS,D.J.; GORIS, M.G.A.; ABDOEL,T.; KAS, J.A.; KNOBBE,S.S.; VAN DONGEN, A.M.; WESTERDUIN, F.E.; KLEIN,W.R.; HARTSKEERL,R.A. Aglutinating antibodies against pathogenic Leptospira in healthy dogs and horses indicate common exposure and regular occurrence of subclinical infections. Veterinary Microbioly, v.148, n. 2-4, p. 449-451, 2011.

JOSEPH, S.; THOMAS, N.; THANGAPANDIAN, E.; SINGH, V.P.; VERMA, R.; SRIVASTAVA, S.K. Evaluation and comparison of native and recombinant LipL21 protein-based ELISAs for diagnosis of bovine leptospirosis. Journal of Veterinary Science. v. 13, n.1, p. 99-101, 2012.
JUNG,B.Y.; LEE.K.W.; HA,T.Y. Seroprevalence of Leptospira spp. in clinically healthy racing horses in Korea. Journal of Veterinary Medical Science. v. 72, n. 2, p. 197-201, 2010.

LA SCOLA, B.; BUI, L.T.; BARANTON, G.; KHAMIS, A.; RAOULT, D. Partial rpoB gene sequencing for identification of Leptospira species. FEMS Microbiology Letters. v. 263, n. 2, p.142-147, 2006. LEVETT, P.N. Leptospirosis. Clinical Microbiology Reviews. v. 14, n. 2, p. 296-326, 2001.

LIMMATHUROTSAKUL, D.; TURNER, E.L.; WUTHIEKANUN, V.; THAIPADUNGPANIT, J.; SUPUTTAMONGKOL, Y.; CHIERAKUL, W.; SMYTHE, L.D.; DAY, N.P.; COOPER, B.; PEACOCK, S.J. Fool's gold: Why imperfect reference tests are undermining the evaluation of novel diagnostics: a reevaluation of 5 diagnostic tests for leptospirosis. Clinical Infectious Diseases. v. 55, n. 3, p. 322331, 2012.

LILENBAUM,W.; RISTOW,P.; FRÁGUAS, S.A.; DA SILVA, E.D. Evaluation of a rapid slide agglutination test for the diagnosis of acute canine leptospirosis. Revista Latino Americana de Microbiología. v. 44, n. 3-4, p.124-128, 2002.

LILENBAUM, W.; VARGES, R.; BRANDÃO, F.Z.; CORTEZ, A.; DE SOUZA, S.O.; BRANDÃO, P.E.; RICHTZENHAIN, L.J.; VASCONCELLOS, S.A. Detection of Leptospira spp. in semen and vaginal fluids of goats and sheep by polymerase chain reaction. Theriogenology. v. 69, n. 7, p. 837-842, 2008.

MAJED, Z.; BELLENGER, E.; POSTIC, D.; POURCEL, C.; BARANTON, G.; PICARDEAU, M. Identification of variable-number tandem-repeat loci in Leptospira interrogans sensu stricto. Journal of Clinical Microbiology. v. 43, n. 2, p. 539-545, 2005.

MARTINS, G.; BRANDÃO, F.Z.; HAMOND, C.; MEDEIROS, M.; LILENBAUM, W. Diagnosis and control of an outbreak of leptospirosis in goats with reproductive failure. The Veterinary Journal, v.193, n. 2, p. 600-601, 2012.

MERIEN, F.; AMOURIAUX, P.; PEROLAT,P.; BARANTON, G.; SAINT GIRONS, I. Polymerase chain reaction for detection of Leptospira spp. in clinical samples. Journal of Clinical Microbiology. v. 30, n. 9, p. 2219-2224, 1992.

MONAHAN, A.M.; CALLANAN, J.J.; NALLY, J.E. Review paper: Host-pathogen interactions in the kidney during chronic leptospirosis. Veterinary Pathology. v. 46, n. 5, p.792-799, 2009.

MUSSO, D.; LA SCOLA, B. Laboratory diagnosis of leptospirosis: A challenge. Journal of Microbiology, Immunology and Infection. 2013. doi:10.1016/j.jmii.2013.03.001.

OIE. Manual of Diagnostic Tests and Vaccines for Terrestrial Animals, $6^{a}$ ed. World Organisation for Animal Health, Paris, 2012.

OTAKA, D.Y.; MARTINS, G.; HAMOND, C.; PENNA, B.; MEDEIROS, M.A.; LILENBAUM, W. Serology and PCR for bovine leptospirosis: herd and individual approaches. Veterinary Record. v.170, n.13, p. 338, 2012.

PAIVA-CARDOSO, M.D.; ARENT, Z.; GILMORE, C.; HARTSKEERL, R.; ELLIS, W.A. Altodouro, a new Leptospira serovar of the Pomona serogroup isolated from rodents in northern Portugal. Infection, Genetics and Evolution. 2013. doi: 10.1016/j. meegid.2012.09.013.

PALANIAPPAN, R.U.; CHANG, Y.F.; CHANG, C.F.; PAN, M.J.; YANG, C.W.; HARPENDING, P.; MCDONOUGH, S.P.; DUBOVI, E.; DIVERS, T.; QU, J.; ROE, B. Evaluation of lig-based conventional and real time PCR for the detection of pathogenic leptospires. Molecular and Cellular Probes, v.19, n. 2, p.111-117, 2005.

PALANIAPPAN, R.U.; RAMANUJAM, S.; CHANG, Y.F. Leptospirosis: pathogenesis, immunity, and diagnosis. Current Opinion in Infectious Diseases, v. 20, n. 3, p. 284-192, 2007.

PICARDEAU, M. Diagnosis and epidemiology of leptospirosis. Médecine et Maladies Infectieuses. v. 43, n. 1, p. 1-9, 2013. 
PINNA, A.E.; MARTINS, G.; HAMOND, C.; LILENBAUM, W.; MEDEIROS, M.A. Molecular diagnostics of leptospirosis in horses is becoming increasingly important. Veterinary Microbiology. v.153, n. 3-4, p. 413, 2011.

PINNA, A.; MARTINS, G.; SOUZA, G.; LILENBAUM, W. Influence of Seroreactivity to Leptospira and reproductive failures in recipient mares of equine embryo transfer programmes. Reproduction in domestic animals, v. 48, n. 4, p. 55-57, 2013.

RAMOS, A.C.; SOUZA, G.N.; LILENBAUM, W. Influence of leptospirosis on reproductive performance of sows in Brazil. Theriogenology. v. 66, n. 4, p. 1021-1025, 2006.

RAHELINIRINA, S.; LÉON, A.; HARSTSKEERL, R.A.; SERTOUR, N.; AHMED, A.; RAHARIMANANA, C.; FERQUEL, E.; GARNIER, M.; CHARTIER, L.; DUPLANTIER, J.M.; RAHALISON, L.; CORNET, M. First isolation and direct evidence for the existence of large small-mammal reservoirs of Leptospira sp. in Madagascar. PLoS One. v. 24, n. 5, p.11, 2010.

RETTINGER, A.; KRUPKA, I.; GRÜNWALD, K.; DYACHENKO, V.; FINGERLE, V.; KONRAD, R.; RASCHEL, H.; BUSCH, U.; SING, A.; STRAUBINGER, R.K.; HUBER, I. Leptospira spp. strain identification by MALDI TOF MS is an equivalent tool to 16S rRNA gene sequencing and multi locus sequence typing (MLST). BMC Microbiology. v. 12, p.185, 2012.

ROMERO, E.C.; BLANCO, R.M.; GALLOWAY, R.L. Application of pulsed-field gel electrophoresis for the discrimination of leptospiral isolates in Brazil. Letters in Applied Microbiology. v. 48, n. 5, p. 623-627, 2009.

SALAÜN, L.; MÉRIEN, F.; GURIANOVA, S.; BARANTON, G.; PICARDEAU, M. Application of multilocus variable-number tandemrepeat analysis for molecular typing of the agent of leptospirosis. Journal of Clinical Microbiology. v. 44, n.11, p. 3954-3962, 2006.

SANKAR, S.; HARSHAN, H.M.; SOMARAJAN, S.R.; SRIVASTAVA, S.K. Evaluation of a recombinant LigB protein of Leptospira interrogans serovar Canicola in an enzyme-linked immunosorbent assay for the serodiagnosis of bovine leptospirosis. Research in veterinary science. v. 88, n. 3, p. 375-378, 2010.

SAUER, S.; KLIEM, M. Mass spectrometry tools for the classification and identification of bacteria. Nature Reviews Microbiology. v. 8, n. 1, p.74-82, 2010.

SLACK, A.T.; SYMONDS, M.L.; DOHNT, M.F.; SMYTHE, L.D. Identification of pathogenic Leptospira species by conventional or real-time PCR and sequencing of the DNA gyrase subunit $B$ encoding gene. BMC Microbiology, v. 6, p. 95, 2006.
SMYTHE, L.; ADLER, B.; HARTSKEERL, R.A.; GALLOWAY, R.L.; TURENNE, C.Y.; LEVETT, P.N. Classification of Leptospira genomospecies 1 , genomospecies 3 , genomospecies 4 and genomospecies 5 as Leptospira alstonii sp. nov., Leptospira vanthielii sp. nov., Leptospira terpstrae sp. nov., Leptospira yanagawae sp. nov., respectively. International Journal of Systematic and Evolutionary Microbiology. 2012. doi: 10.1099/ ijs.0.047324-0

STODDARD, R.A.; GEE, J.E.; WILKINS, P.P.; MCCAUSTLAND, K.; HOFFMASTERA, A.R. Detection of pathogenic Leptospira spp. through TaqMan polymerase chain reaction targeting the LipL32 gene. Diagnostic Microbiology and Infectious Disease. v. 64, n. 3, p. 247-255, 2009.

SUBATHRA, M.; SENTHILKUMAR, T.M.; RAMADASS, P. Recombinant OmpL1 protein as a diagnostic antigen for the detection of canine leptospirosis. Applied Biochemistry and Biotechnology. v.169, n. 2, p. 431-437, 2013.

SUEPAUL, S.M.; CARRINGTON, C.V.; CAMPBELL, M.; BORDE, G.; ADESIYUN, A.A. Seroepidemiology of leptospirosis in livestock in Trinidad. Tropical Animal Health Production. v. 43, n. 2, p. 367375, 2011.

SYKES, J.E.; HARTMANN, K.; LUNN, K.F.; MOORE, G.E.; STODDARD, R.A.; GOLDSTEIN, R.E. 2010 ACVIMsmall animal consensus statement on leptospirosis: diagnosis, epidemiology, treatment, and prevention. Journal of Veterinary Internal Medicine. v. 25, n. 1, p.1-13, 2011.

SZEREDI, L.; HAAKE, D.A. Immunohistochemical identification and pathologic findings in natural cases of equine abortion caused by leptospiral infection. Veterinary Pathology. v. 43, n. 5, p. 755761, 2006

TOYOKAWA, T.; OHNISHI, M.; KOIZUMI, N. Diagnosis of acute leptospirosis. Expert Review of Anti-infective Therapy. v. 9, n. 1, p. 111-121, 2011.

WORLD HEALTH ORGANIZATION (WHO). Report of the first meeting of leptospirosis burden epidemiology reference group. Geneva: p.1-34, 2010.

YAN, W.; SALEEM, M.H.; MCDONOUGH, P.; MCDONOUGH, S.P.; DIVERS, T.J.; CHANG, Y.F. Development of an enzymelinked immunosorbent assay using a recombinant LigA fragment comprising repeat domains 4 to 7.5 as an antigen for diagnosis of equine leptospirosis. Clinical and Vaccine Immunology. v. 20, n. 8 , p.1143 -1149, 2013. doi:10.1128/CVI.00245-13. 